\title{
The Relationship between Obstructive Sleep Apnea and GIn223Arg Polymorphism in Human Leptin Receptor Gene
}

\author{
Serkan Kuccukturk ${ }^{1 *}$, Sebnem Yosunkaya ${ }^{2}$, Hacer Kuzu Okur ${ }^{3}$, Seyit Ali Kayis ${ }^{4}$, \\ Sennur Demirel ${ }^{1}$, Hasibe Cingilli Vural ${ }^{1}$
}

'Necmettin Erbakan University, Meram Faculty of Medicine, Department of Medical Biology, Konya, Turkey

${ }^{2}$ Necmettin Erbakan University, Meram Faculty of Medicine, Department of Chest Diseases, Konya, Turkey

${ }^{3}$ Acıbadem Altunizade Hospital, Clinic of Chest Diseases, Istanbul, Turkey

${ }^{4}$ Karabuk University, Faculty of Medicine, Department of Biostatistics, Karabuk, Turkey

Please cite this article as: Kuccukturk S, Yosunkaya S, Kuzu Okur H, Kayis SA, Demirel S, Cingilli Vural H. The Relationship between Obstructive Sleep Apnea and Gln223Arg Polymorphism in Human Leptin Receptor Gene. Eur J Biol 2017; 76(2): 43-50.

\begin{abstract}
Leptin is derived from an adipocyte and acts through the leptin receptor (LEPR). Gln223Arg polymorphism of the LEPR gene is thought to be associated with impaired signaling capacity of $L E P R$ and with higher mean circulating levels of leptin and obesity; therefore, it may contribute to the pathogenesis of obstructive sleep apnea syndrome (OSAS). The aim of this study was to investigate the frequency of distribution of LEPR gene polymorphism (Gln223Arg) in OSAS patients in relation to polysomnographic traits and phenotype.

In total, 230 men (152 OSAS patients and 78 controls) were included in the study. All participants were evaluated by polysomnography in addition to anthropometric, metabolic, and hemodynamic variables. The relationship between these phenotypes and polymorphism of the LEPR gene was investigated by PCR-RFLP.

There was no difference between the genotype frequencies of the Gln223Arg polymorphism in the OSAS and control groups. However, OSAS patients carrying the R allele (RR and QR genotypes) had significantly lower Body Mass Index (BMI) than those carrying the $\mathrm{Q}$ allele (QQ). OSAS patients with the RR genotype had a significantly lower diastolic blood pressure value than those with the $\mathrm{QQ}$ and $\mathrm{QR}$ genotypes. When all participants were grouped by blood pressure, the genotype frequency of RR individuals was more prevalent among normotensive men compared to hypertensive men.

Gln223Arg polymorphism of LEPR does not seem to be associated with OSAS. This polymorphism may, however, predispose the carrier to reduced BMI and blood pressure. Further studies are needed to unveil the genetic basis of OSAS pathophysiology.
\end{abstract}

Keywords: Blood pressure, gln223arg, leptin receptor polymorphism, leptin, obstructive sleep apnea

\section{INTRODUCTION}

Obstructive sleep apnea (OSA) is characterized by recurrent episodes of upper airway collapse during sleep, which in turn trigger apneas and hypopneas associated with oxyhemoglobin desaturation and arousal from sleep (1). Elevated Apnea-Hypopnea Index (AHI) indicating the severity of the disease in conjunction with hyper somnolence, or related problems in daytime functioning is called OSA syndrome (OSAS) (2). Cardiovascular and metabolic abnormalities are frequent in patients with OSAS (dyslipidemia, hypertension, and diabetes mellitus type 2 , along with their cardiovascu- lar consequences) (3,4). Indeed, OSAS is strongly correlated with obesity and obesity-related variables such as body mass index (BMI), neck circumference, and visceral fat deposition $(5,6)$. Recently, it has been speculated that changes in serum leptin levels and leptin-receptor insensitivity may be involved in the pathogenesis of progressive obesity and metabolic abnormalities in patients with OSAS $(7,8)$.

Given the prominence of obesity in the OSAS phenotype, the genetic underpinning of obesity is highly relevant to the study of the genetic basis of OSAS. Furthermore, a number of genes implicated in obesity 
have also been associated with physiological systems relevant to OSAS. For example, leptin, adenosine deaminase, and melanocortin-4 receptor are expressed in a variety of tissues and brain sites important in the regulation of breathing (9). There is growing evidence that leptin, in particular, may possess pleiotropic effects. In addition to its role in appetite regulation and energy expenditure, studies on mouse models suggest that leptin influences lung growth and respiratory control. Leptin treatment also influences sleep architecture in rats. If confirmed humans, these data strongly support the idea that a single gene is implicated in several aspects of the OSAS phenotype (obesity, ventilator control, sleep architecture) (10).

Leptin acts via the leptin receptor (LEPR), which is involved the class I cytokine receptor family. Several single-nucleotide polymorphisms (SNPs) have been described in the human LEPR (e.g., Gln223Arg, Ser343Ser, Ser492Thr, Lys656Asn) of which Gln223Arg (Q223R) is the most common type $(11,12)$. The extracellular region of the LEPR within the first cytokine domain (C domain) containing a leptin-binding site contains the Q223R substitution in exon 6 . Consequently, the amino acid change affects all forms of the receptor (13). Therefore this polymorphism of the leptin receptor has been associated with higher level of circulating leptin obesity (as defined by elevated BMI), insulin resistance, and dyslipidemia (14-19). Ogawa et al. (14) reported that the serum soluble leptin receptor (sOB-R) level was negatively correlated with homeostasis model assessment-estimated insulin resistance and serum leptin level and positively correlated with high-density lipoprotein (HDL)-cholesterol and serum adiponectin levels, independent of age, sex, and BMI, in healthy Japanese subjects . Ragin et al. (15) reported higher mean circulating leptin levels of LEPR R223R genotype in post-menopausal Caucasian women. Yiannakouris et al. (19) showed that Q223R polymorphism was associated with obesity and predicts approximately $5 \%$ of body weight and body composition variability in the Greek population. Hastuti et al. (20) reported that Q223R polymorphism and phenotype of obesity was associated in the Yogyakarta population. Lv et al. (21) analyzed that there was an association between GIn233Arg polymorphism and OSA risk in European but not for Asian populations (22).

The purpose of this study is to investigate the genotype distribution and the allele frequency of LEPR Q223R polymorphism in OSAS patients and to estimate the effect of this polymorphism on metabolic and anthropometric traits.

\section{MATERIALS AND METHODS}

\section{Study Population}

Out of 857 admittants who had complaints of unintentional sleep episodes during wakefulness, daytime sleepiness, unrefreshing sleep, fatigue, insomnia; or loud snoring, breathing interruptions, gasping or choking during sleep; 230 males that were between the ages of 18-70 were included. These patients admitted in the sleep center with their own will and didn't carry the exclusion criteria. Only male subjects were included to eliminate gender-specific genetic and metabolic factors that may be involved in OSAS. Subjects were collected between the years of 2008 and 2011.

After giving a written, informed consent individuals were evaluated on the basis of a detailed physical examination and history for inclusion and exclusion criteria. All subjects had their height, weight, neck circumference and blood pressure measured, and were asked to fill out a standard sleep questionnaire (including an Epworth Sleepiness Scale sheet; ESS) (23). Neck circumference was measured at the level of the cricoid and waist circumference at the level of the umbilicus. BMI was calculated as the weight in kilograms divided by the square of the height in meters $\left(\mathrm{kg} / \mathrm{m}^{2}\right)$. Systolic blood pressure (SBP) and diastolic blood pressure (DBP) were measured twice with the subjects in the sitting position after resting for at least 5 minutes. To define hypertension, the SBP cut offs in all subjects were set to $\geq 140 \mathrm{~mm} \mathrm{Hg}$, and the DBP cut off was set to $\geq 90$ for hypertension and $<140 / 90 \mathrm{~mm} \mathrm{Hg}$ for normal blood pressure (24).

Patients with any of the following characteristics were excluded from the study: history of cerebrovascular or cardiovascular disease, diabetes (previous diagnosis or fasting blood glucose $>126 \mathrm{mg} / \mathrm{dL}$ ), endocrine disease, significant renal or hepatic disease; age $<18$ or $>70$ years old; a diagnosis of central sleep apnea or Cheyne-Stokes respiration; clinical manifestation of severe chronic obstructive pulmonary disease or asthma (postbronchodilator $\mathrm{FEV} 1<70 \%$ predicted); and hypertensives on medication for hypertension.

To confirm the diagnosis, all study groups underwent full-night standard polysomnography. The subject with $\mathrm{AHI} \geq 5$ were diagnosed as patients $(n=152)$; those with $A H I<5$ defined as controls $(n=78)$. The patient group consisted of overweight or obese $\left(\mathrm{BMl} \geq 25 \mathrm{~kg} / \mathrm{m}^{2}, \mathrm{n}=86\right)$ and non-obese $\left(\mathrm{BMl}<25 \mathrm{~kg} / \mathrm{m}^{2}\right.$, $\mathrm{n}=66$ ) individuals (25), while our control group was composed of non-obese $\left(\mathrm{BMl}<25 \mathrm{~kg} / \mathrm{m}^{2}\right)$ individuals with no sleep or respiratory problems. The patients were further classified into three subgroups according to the AHI of each OSAS patient: mild OSAS $(5 \leq \mathrm{AHI}<15)$, moderate OSAS $(15 \leq \mathrm{AHI}<30)$ and severe OSAS ( $\geq 30)(26)$.

To assay for the presence of comorbid disorders, we performed complete blood count and tests for liver, renal, and thyroid function. Hemogram, total cholesterol, triglycerides (TG), HDL-cholesterol, and low-density lipoprotein (LDL)-cholesterol levels were determined, in addition to ECG, chest X ray, and spirometry. The local Ethics Committee approved this study and written consent was obtained from every participant.

\section{Sleep Study}

An overnight polysomnography was performed on each subject using the digital polysomnographic system (VIASYS Healthcare $\mathrm{GmbH}$, Hoechberg, Germany). For each subject, we obtained electroencephalograms (3 channels: C3A2, C4A1, and $\mathrm{O} 2 \mathrm{~A} 1$ ), left and right electrooculograms, and a chin electromyogram from surface leads. We used nasal cannula and a thermistor to measure airflow, thoracic and abdominal belts to quanti- 
fy respiratory effort, a tracheal microphone to record snoring, a pulse oximeter to measure nocturnal oxygen saturation (NOS) and heart beat speed, and a sensor to collect information on body position during sleep. Sleep staging and respiratory event scoring were performed manually according to the AASM criteria (26): Apnea was defined as cessation of airflow for $\geq 10$ s; hypopnea as $\geq 50 \%$ reduction of baseline airflow for at least 10 s and $\geq 3 \%$ desaturation from present baseline or in case the event is associated with arousal; obstructive respiratory event was scored if it meets apnea criteria and is associated with continued or increased inspiratory effort throughout the entire period of absent airflow respiratory events the which continued thorax and abdominal movements during apnea were defined as obstructive.

\section{Genetic Experiments}

Peripheral blood samples were obtained from all patients. DNA was isolated from leukocytes by using phenol chloroform isolation methods (27) and maintained in $500 \mu$ l of $10 \mathrm{mM}$ Tris buffer solution. Qualitative and quantitative analysis of DNA was undertaken spectrophotometrically. The LEPR Q223R (Gln223Arg or 668A/G-rs1137101 or Glutamine (Q) 223Arginine (R)) polymorphic region was amplified by polymerase chain reaction (PCR). For each sample, genomic DNA of $50-100 \mathrm{ng} / \mu \mathrm{l}$ was used in a 20- $\mu$ PCR reaction. Previously reported (28) 5'-ACC CTTTAA GCT GGG TGT CCC AAA TAG-3' forward and 5'-AGCTAG CAA ATA TTT TTG TAA GCA ATT-3' reverse primer pair was used for 20 $\mu \mathrm{l}$ reaction mixture in concentrations $1 \mathrm{X}$ buffer, 0,025 $\mathrm{U} / \mu \mathrm{l}$ Taq polymerase, $1.5 \mathrm{mM} \mathrm{MgCl}, 0.2 \mathrm{mM}$ deoxynucleoside triphosphates, and $2 \mathrm{mM}$ each primer supplied by SibEnzyme (Novosibirsk, Russia). The PCR protocol used was as follows: onset of denaturation at $94^{\circ} \mathrm{C}$ for $8 \mathrm{~min}$, [denaturation at $94^{\circ} \mathrm{C}$ for $45 \mathrm{~s}$; annealing at $65^{\circ} \mathrm{C}$ for $45 \mathrm{~s}$; extension at $72^{\circ} \mathrm{C}$ for $90 \mathrm{~s}$ ] 30 cycles and final extension at $72^{\circ} \mathrm{C}$ for $10 \mathrm{~min}$.

Polymerase chain reaction products of a length of $416 \mathrm{bp}$ were incubated at $37^{\circ} \mathrm{C}$ overnight with $10 \mathrm{U} / \mu \mathrm{l} \mathrm{Mspl} \mathrm{restriction} \mathrm{en-}$ zyme (SibEnzyme, Novosibirsk, Russia) with a C^CGG (cutting site) identification point appropriate for the LEPR Q223R polymorphism. To visualize the DNA fragments, a current of $120 \mathrm{~V}$ was applied for $20 \mathrm{~min}$.

\section{Statistical Analysis}

Descriptive statistics were obtained for clinical and biochemical traits. The Mann-Whitney $U$ test was employed for initial comparison of patient and control groups. Chi-square goodness of fit test was carried out to evaluate for Hardy-Weinberg equilibrium (HWE) in the patient and control groups. Genotype frequencies were compared between groups of hypertensive and normotensive individuals. Analyses were performed using co-dominant, dominant, and recessive models for evaluating the potential effect of R223 (Arg) allele. Dominant or recessive models were defined in terms of $\mathrm{R}$ allele effects. In dominant $\mathrm{R}$ allele models, homozygous individuals for $\mathrm{Q}$ allele were compared with carriers of $R$ allele. In recessive $R$ allele models, homozygous individuals for $R$ allele were compared with carriers of $\mathrm{Q}$ allele. ANOVA was performed in the co-dominant model and an independent $t$ test was used in the other genetic models to perform a comparative evaluation of the variables LDL and cholesterol. The results of the variables LDL and cholesterol were expressed as mean $\pm S D$ (standard deviation). To evaluate the other clinical and biochemical variables, the Kruskal Wallis test was performed in the co-dominant model and Mann-Whitney $U$ test was performed in the dominant and recessive models. Logarithmic transformation (Log 10) was applied to triglyceride measurements, as they were not normally distributed. Log transformation and nonparametric test results were expressed as a back transformed mean $\pm 95 \% \mathrm{Cl}$ and median (quartile 1-3), respectively. Odds ratios (ORs) between hypertensive and normotensive groups were obtained to establish the relationship between the SNP allele and hypertension. Pearson correlation was applied between $\mathrm{AHI}$, BMI, waist and neck circumferences. With the current sample size set up, an obstructive difference between the genotypes of 8 unit would be detected with a $70 \%$ chance at $a=0.05$ level. Analyses were carried out using R 2.11.1 (R Foundation for Statistical Computing, Vienna, Austria) (29). In all analyses, a $P$ value of $<0.05$ was considered to be statistically significant.

\section{RESULTS}

Demographics and other parameters for both groups were shown in Table 1. BMI $\left(\mathrm{kg} / \mathrm{m}^{2}\right)$, neck and waist circumference $(\mathrm{cm})$, systolic and diastolic blood pressure ( $\mathrm{mm} \mathrm{Hg}$ ), ESS were found to be higher in OSAS patients. Nocturnal mean oxygen saturation [NOS (\%)] was significantly lower in the OSAS patient group (Table 1). 52 of the participants were hypertensive. In patients with OSAS compared to the control group was higher the proportion of hypertensive. There was no significant difference between patients and controls for genotype distribution and allele frequencies of LEPR Q223R polymorphism (Table 2).

Since genotype frequencies were similar in both OSAS patient and control groups, OSAS patients were subgrouped according to $\mathrm{AHI}$ and $\mathrm{BMI}$ indices to discern more distinctly the potential impact of the alleles on health. In the subgroup classified according to BMI, a significant difference in allele frequency and genotype distribution was observed under the dominant and co-dominant models. However, no such differences were observed with respect to $\mathrm{AHI}$ severity (Table 3 ).

In OSAS patients, $\mathrm{AHI}$ was positively correlated with $\mathrm{BMI}$ and both waist and neck circumferences ( $r=0.233, r=0.244$ and $r=0.232$, respectively all $p<0.05$ ).

In OSAS patients, BMI value of men who were carrying the $\mathrm{R}$ allele was significantly lower than those who did not have the $R$ allele under the dominant model $(p=0.03)$. Furthermore, we observed lower diastolic blood pressure in men with the RR genotype under the recessive model $(p=0.01)$. Lower AHI values were also noted in men with the RR genotype under the recessive model $(p=0.04)$ and higher NOS values were noted in men with the RR genotype under the co-dominant model $(p=0.001)$ and recessive model $(p=0.002)$ (Table 4). However, no associations were observed between genotypes and values of 
Table 1. Demographics and other parameters in OSAS patient and control groups

\begin{tabular}{lccc}
\hline & $\begin{array}{c}\text { Patients } \\
(\mathbf{n = 1 5 2})\end{array}$ & $\begin{array}{c}\text { Controls } \\
(\mathbf{n = 7 8 )}\end{array}$ & $\mathbf{p}$ \\
\hline Age $(\mathrm{y})$ & $47.00(41-56)$ & $46.00(43-50)$ & 0.500 \\
\hline $\begin{array}{l}\text { Body Mass Index } \\
\left(\mathrm{kg} / \mathrm{m}^{2}\right)\end{array}$ & $\begin{array}{c}30.31(23.7- \\
33.8)\end{array}$ & $23.00(23.1-24)$ & $<0.001$ \\
\hline
\end{tabular}

Neck

Circumference

$\begin{array}{lllll}(\mathrm{cm}) & 43 & (40-45) & 40 & (38-41)\end{array} \quad<0.001$

Waist

Circumference

$\begin{array}{lllll}(\mathrm{cm}) & 106(99-116) & 98 & (94-100) & <0.001\end{array}$

Apnea-Hypopnea

\begin{tabular}{lccccc|} 
Index (events/h) & 33.60 & $(19-58.1)$ & 2.40 & $(1.1-4.2)$ & $<0.001$ \\
\hline NOS (\%) & $91(89-93)$ & 93 & $(92-95)$ & $<0.001$ \\
\hline
\end{tabular}

Epworth

Sleepiness Scale $\quad 10(6-15) \quad 7 \quad(3-10) \quad<0.001$

Systolic Blood

Pressure $(\mathrm{mmHg}) \quad 130(120-140) \quad 120 \quad(110-130)<0.001$

Diastolic Blood

$\begin{array}{lllll}\text { Pressure }(\mathrm{mmHg}) \quad 80 & (70-90) & 70 & (70-80) & 0.004\end{array}$

$\begin{array}{llll}\begin{array}{l}\text { Cholesterol } \\ (\mathrm{mg} / \mathrm{dL})^{*}\end{array} & 213.6 \pm 43.23 & 190.8 \pm 28.94 & >0.05\end{array}$

Triglyceride

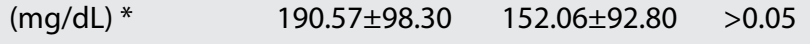

Low Density

Lipoprotein

$(\mathrm{mg} / \mathrm{dL})$ *

$135.47 \pm 32.4$

$120.60 \pm 24.97>0.05$

High Density

Lipoprotein

\begin{tabular}{llll}
$(\mathrm{mg} / \mathrm{dL}){ }^{*}$ & $38.58 \pm 7.90$ & $40.63 \pm 6.02$ & $>0.05$ \\
\hline Hypertensive & $44(28.94 \%)$ & $8(10.25 \%)$ & $<0.05$
\end{tabular}

Values were expressed as median (quartile 1-3)

*Values were expressed as mean \pm standard deviation

NOS: nocturnal oxygen saturation; OSAS: OSA syndrome

waist circumference, neck circumference, lipid profiles, SBP, and ESS scores ( $p>0.05$ ) (Table 4).

When all subjects were classified according to blood pressure (Table 5), the RR genotype appeared to be absent among individuals with hypertension. The odds ratios and $95 \%$ confidence intervals $(\mathrm{Cl})$ determined suggested that $\mathrm{Q}$ allele carriers were at higher risk for hypertension than $\mathrm{R}$ allele carriers. The odds ratio results were as follows: $O R=2.29$ ([\%95 Cl 1.36-3.83], $p=0.002$ ) for $\mathrm{R}$ vs. $\mathrm{Q}$ alleles; $\mathrm{OR}=1.77$ ([\%95 Cl 0.9-3.32], $\mathrm{p}=0.83$ ) for $\mathrm{QR}$ vs. QQ, all under a co-dominant model; $\mathrm{OR}=2.26$ ([\%95 Cl 1.214.19], $p=0.012$ ) for $Q R+R R$ vs. $Q Q$ under the dominant model.

An analysis of the systolic and diastolic blood pressures for all groups led us to understand that both were lower in subjects with the RR genotype. Genotypic differences in SBP were statistically insignificant under the co-dominant and dominant models, while they were significant under the recessive model $(p=0.046)$ (Table 6). There was no significant difference in diastolic blood pressure between the genotypes under any of the genetic models.

\section{DISCUSSION}

There was no deviation from Hardy-Weinberg equilibrium in the patient and control groups. In addition, no difference was found in genetic distribution for OSAS patients with different AHI. Thus, present results do not support our initial hypothesis that the polymorphism is associated with OSAS. There is limited data on the occurrence of LEPR Q223R polymorphism in OSAS patients. To our knowledge, three other studies on this issue reported results consistent with ours. Hanaoka et al. (30) and Huang et al. (31) have demonstrated that genotype distribution and allele frequencies did not differ in OSAS patients and controls in Japanese populations. Hanaoka et al. (30) suggested that there was a barely significant relationship between the severity of OSAS and the dominant model including groups with or without the $\mathrm{R}$ allele. Ultimately, these authors have concluded, as we have, that the LEPR Q223R polymorphism was not directly associated with polysomnographic traits and OSAS phenotype. Also, Li et al. (32) reported that association between LEPR and OSAS was not been in Chinese Han population. In contrast, Popko et al. (33) suggested that presence of an $R$ allele in this polymorphism was associated with obesity, thereby constituting a risk factor for OSAS. OSAS is a multi-systemic disorder related to multiple genetic, environmental, and developmental factors and is therefore unlikely to be determined by a single gene mutation. Maxillofacial morphology, respiratory chemo sensitivity, sympathetic nervous system activity, muscular fatigue, hormone levels, and obesity are other parameters that may contribute to the pathogenesis of OSAS (10). Gln223Arg gene polymorphism or LEPR polymorphisms affect obesity, which is a risk factor in OSAS. Also, the studies of population differences between OSAS and Q223R gene polymorphism are insufficient in the literature and its role in the Turkish population is unknown.

Obesity, central obesity in particular $(5,6)$, is commonly identified as a major OSAS risk factor (10). However, several studies on the association between LEPR polymorphisms and BMI have revealed mixed results. For example, Stefan et al. (34) and Gotoda et al. (35) have claimed that Q223R polymorphism has no effect on obesity (11) and only a weak association was established between BMI and Q223R polymorphism in the obese Turkish population in another study (36). Yiannakouris et al. (19) have investigated Q223R, K109R, and K656N polymorphisms in the Mediterranean population, and suggested that not only Q223R was not associated with obesity, but it was also a weak 
Table 2. Frequency distribution of genotype and alleles in patient and control groups

\begin{tabular}{|c|c|c|c|c|c|c|c|c|c|}
\hline \multirow[b]{3}{*}{ Total } & \multicolumn{7}{|c|}{ Frequency of Genotype } & & \\
\hline & \multicolumn{3}{|c|}{ Co-Dominant Model } & \multicolumn{2}{|c|}{ Dominant Model } & \multicolumn{2}{|c|}{ Recessive Model } & \multicolumn{2}{|c|}{ Frequency of Alleles } \\
\hline & QQ & QR & $\mathbf{R R}$ & QQ & QR/RR & QQ/QR & $\mathbf{R R}$ & $\mathbf{Q}$ & $\mathbf{R}$ \\
\hline Patients $n=152$ & $71(46.7)$ & $70(46.1)$ & $11(7.2)$ & $71(46.7)$ & $81(53.3)$ & $141(92.8)$ & $11(7.2)$ & $212(69.3)$ & $92(30.7)$ \\
\hline Control $n=78$ & $30(38.5)$ & $36(46.2)$ & $12(15.4)$ & $30(43.8)$ & $48(56.2)$ & $66(84.6)$ & $12(15.4)$ & $96(62.5)$ & $60(37.5)$ \\
\hline$\chi^{2 / p}$ & \multicolumn{3}{|c|}{$4.22 / 0.12$} & \multicolumn{2}{|c|}{$1.42 / 0.26$} & \multicolumn{2}{|c|}{$3.80 / 0.06$} & \multicolumn{2}{|c|}{$2.77 / 0.09$} \\
\hline
\end{tabular}

Table 3. Genotype frequencies with regard to Apnea-Hypopnea Index and Body Mass Index in the patient group

\begin{tabular}{|c|c|c|c|c|c|c|c|c|}
\hline & \multirow{3}{*}{$\begin{array}{c}\begin{array}{c}\text { OSAS group } \\
(n=152)\end{array} \\
\text { Genotypes }\end{array}$} & \multicolumn{4}{|c|}{ Apnea-Hypopnea Index } & \multicolumn{3}{|c|}{ Body Mass Index } \\
\hline & & & & & & & Non-obese & \\
\hline & & Mild & Moderate & Severe & $x^{2} / p$ & Obese OSAS & OSAS & $x^{2} / p$ \\
\hline \multirow[t]{3}{*}{ Co-Dominant Model } & QQ & $10(14.1)$ & $20(28.2)$ & $41(57.7)$ & \multirow{3}{*}{$1.72 / 0.42$} & $47(66.2)$ & $24(33.8)$ & \multirow{3}{*}{$8.15 / 0.02$} \\
\hline & QR & $15(21.4)$ & $15(21.4)$ & $40(57.1)$ & & $31(44.3)$ & $39(55.7)$ & \\
\hline & $\mathrm{RR}$ & $3(27.3)$ & $5(45.5)$ & $3(27.3)$ & & $8(72,7)$ & $3(27.3)$ & \\
\hline \multirow[t]{2}{*}{ Dominant Model } & QQ & $10(14.1)$ & $20(28.2)$ & $41(57.7)$ & \multirow{2}{*}{$1.68 / 0.43$} & $47(66.2)$ & $24(33.8)$ & \multirow{2}{*}{$5.01 / 0.03$} \\
\hline & $\mathrm{QR}+\mathrm{RR}$ & $18(22.2)$ & $20(24.7)$ & $43(53.1)$ & & $39(48.1)$ & $42(51.9)$ & \\
\hline \multirow[t]{2}{*}{ Recessive Model } & $\mathrm{QQ}+\mathrm{QR}$ & $25(17.7)$ & $35(24.8)$ & $81(57.4)$ & \multirow{2}{*}{$3.83 / 0.15$} & $78(55.3)$ & $63(44.7)$ & \multirow{2}{*}{$1.26 / 0.35$} \\
\hline & $\mathrm{RR}$ & $3(27.3)$ & $5(45.5)$ & $3(27.3)$ & & $8(72.7)$ & $3(27.3)$ & \\
\hline
\end{tabular}

Values were expressed as number of individuals and (\%)

determinant of body fat composition. In our study, in OSAS group, AHI was positively correlated with $\mathrm{BMI}$, neck and waist circumference. Patients with OSAS were divided according to $\mathrm{BMI}$ and were found to differ in genotype frequency under the co-dominant and dominant models. We demonstrated that the $\mathrm{BMI}$ values of $\mathrm{R}$ allele carriers were lower compared to the QQ genotype under the dominant model. The severity of OSAS was decreased in R allele carriers having lower BMI. Lower AHI value in RR genotype under recessive model was distinctive. In agreement with our results, Ben Ali et al. (37) reported that in obese Tunisian men, QR and RR genotypes were associated with lower BMI compared to the QQ genotype . Guizar-Mendoza (28) reported that the RR genotype was more associated with lower body fat percentage compared to $\mathrm{QQ}$ and $\mathrm{QR}$ genotypes.

The importance of the polymorphism in LEPR on the human body composition has also been reported in a few studies $(38,39)$. Wauters et al. (39) reported that in postmenopausal Caucasian women, the total abdominal fat level, as measured by CT, was higher in Q223 homozygotes. Also, negative results have been reported for the polymorphism in other populations. Heo et al. (40) analyzed entries collected from 9 studies on the LEPR for the association between 3 alleles (Lys109Arg, Gln223Arg and
Lys656Asn) with BMI and waist circumference. They reported that there was no association between common LEPR polymorphisms (Lys109Arg, Gln223Arg and Lys656Asn) and BMI or waist circumference in a meta-analysis. In this study, we similarly concluded that the Q223R polymorphism was not associated with neck or waist circumference in patients with OSAS.

We found some differences in the AHI values between the genotypes studied under the recessive model. Differences in the NOS values were also significant across different genotypes under both co-dominant and recessive models. Lower $\mathrm{AHI}$ values and higher NOS levels in subjects with a RR genotype led us to hypothesize that the RR genotype can also have an impact on the BMI. Additionally, diastolic blood pressure was associated with certain genotypes under the recessive model, while systolic blood pressure was not significantly different in the various genetic models in OSAS patients. Interestingly, patients with the RR genotype were found to have lower blood pressure levels compared to those carrying a QQ or QR allele. Previously, Rosmond et al. (41) revealed that the disruption of $L E P R$ signal might affect sympathetic activation in obese subjects. Similarly, we have examined this condition in all individuals in this study. We evaluated the frequencies of genotypes and allelic distribution after 
Table 4. Demographics and other parameters compared with genetic models of OSAS patients

\begin{tabular}{|c|c|c|c|c|c|c|c|}
\hline \multirow{3}{*}{$\begin{array}{l}\text { OSAS Group } \\
(n=152)\end{array}$} & \multicolumn{7}{|c|}{ Genotype } \\
\hline & \multicolumn{3}{|c|}{ Co-Dominant Model } & \multicolumn{2}{|c|}{ Dominant Model } & \multicolumn{2}{|c|}{ Recessive Model } \\
\hline & QQ & QR & $\mathbf{R R}$ & QQ & QR/RR & QQ/QR & $\mathbf{R R}$ \\
\hline & 71 & 70 & 11 & 71 & 81 & 141 & 11 \\
\hline $\mathrm{Age}^{\dagger}$ & $47.76 \pm 9.1$ & $49.10 \pm 10.7$ & $43.18 \pm 8.2$ & $47.76 \pm 9.1$ & $48.30 \pm 10.6$ & $48.43 \pm 10.0$ & $43.18 \pm 8.2$ \\
\hline $\begin{array}{l}\text { Body Mass } \\
\text { Index }\end{array}$ & $\begin{array}{c}31.22^{¥} \\
(24.0-35.4)\end{array}$ & $\begin{array}{c}24.10 \\
(23.7-32.5)\end{array}$ & $\begin{array}{c}30.45 \\
(23-32.7)\end{array}$ & $\begin{array}{c}31.22 \\
(24.0-35.4)\end{array}$ & $\begin{array}{c}24.0^{*} \\
(23.1-32.7)\end{array}$ & $\begin{array}{c}30.30 \\
(23.7-34.1)\end{array}$ & $\begin{array}{c}30.45 \\
(23-32.7)\end{array}$ \\
\hline $\begin{array}{l}\text { Neck } \\
\text { Circumference }\end{array}$ & $\begin{array}{c}43 \\
(40.5-45)\end{array}$ & $\begin{array}{c}42 \\
(40-44.8)\end{array}$ & $\begin{array}{c}43 \\
(42-44.5)\end{array}$ & $\begin{array}{c}43 \\
(40.5-45)\end{array}$ & $\begin{array}{c}42 \\
(40-45)\end{array}$ & $\begin{array}{c}43 \\
(40-45)\end{array}$ & $\begin{array}{c}43 \\
(42-44.5)\end{array}$ \\
\hline $\begin{array}{l}\text { Waist } \\
\text { Circumference }\end{array}$ & $\begin{array}{c}109 \\
(99-117.5)\end{array}$ & $\begin{array}{c}105.5 \\
(99-114.5)\end{array}$ & $\begin{array}{c}105 \\
(102-110.5)\end{array}$ & $\begin{array}{c}109 \\
(99-117.5)\end{array}$ & $\begin{array}{c}105 \\
(99-115)\end{array}$ & $\begin{array}{c}107 \\
(99-116)\end{array}$ & $\begin{array}{c}105 \\
(102-110.5)\end{array}$ \\
\hline $\begin{array}{l}\text { Apnea - } \\
\text { Hypopnea } \\
\text { Index }\end{array}$ & $\begin{array}{c}37 \\
(21.2-60.7)\end{array}$ & $\begin{array}{c}33.6 \\
(17.9-59.8)\end{array}$ & $\begin{array}{c}20.8 \\
(14.7-28.4)\end{array}$ & $\begin{array}{c}37 \\
(21.2-60.7)\end{array}$ & $\begin{array}{c}32 \\
(17.5-52.5)\end{array}$ & $\begin{array}{c}35.9 \\
(19.3-61.3)\end{array}$ & $\begin{array}{c}20.8^{*} \\
(14.7-28.4)\end{array}$ \\
\hline NOS & $91(89-93)$ & $91(88-92)$ & $93(92.5-94)^{*}$ & $91(89-93)$ & $91(89-93)$ & $91(88-93)$ & $93(92.5-94)^{*}$ \\
\hline ESS & $11(6-16)$ & $10(6.3-13)$ & $10(8.5-12)$ & $11(6-16)$ & $10(7-13)$ & $10(6-15)$ & $10(8.5-12)$ \\
\hline SBP & $130(120-140)$ & $130(120-140)$ & $120(115-130)$ & $130(120-140)$ & $130(120-140)$ & $130(120-140)$ & $120(115-130)$ \\
\hline DBP & $80(70-90)$ & $80(70-90)$ & $70(65-70)$ & $80(70-90)$ & $80(70-90)$ & $80(70-90)$ & $70(65-70)^{*}$ \\
\hline
\end{tabular}

Table 5. Genotype frequencies of subjects with hypertensive and normotensive values

\begin{tabular}{|c|c|c|c|c|c|c|c|c|c|}
\hline & \multicolumn{3}{|c|}{ Co-Dominant Model } & \multicolumn{2}{|c|}{ Dominant Model } & \multicolumn{2}{|c|}{ Recessive Model } & \multicolumn{2}{|c|}{ Frequency of Alleles } \\
\hline & QQ & QR & $\mathbf{R R}$ & QQ & QR/RR & QQ/QR & RR & $\mathbf{Q}$ & $\mathbf{R}$ \\
\hline \multirow[t]{2}{*}{ Hypertensive $(n=54)$} & $32(59.3)$ & $22(40.7)$ & - & $32(59.3)$ & $22(40.7)$ & $54(100)$ & - & $86(79.6)$ & $22(20.4)$ \\
\hline & $69(39.2)$ & $84(47.7)$ & $\begin{array}{c}23 \\
(13.1)\end{array}$ & $69(39.2)$ & $\begin{array}{c}107 \\
(60.8)\end{array}$ & $153(86.9)$ & $\begin{array}{c}23 \\
(13.1)\end{array}$ & $222(63.1)$ & $130(36.9)$ \\
\hline$x^{2} / p$ & \multicolumn{3}{|c|}{$11.279 / 0.004$} & \multicolumn{2}{|c|}{$6.748 / 0.012$} & \multicolumn{2}{|c|}{$7.841 / 0.03$} & \multicolumn{2}{|c|}{$9.51 / 0.001$} \\
\hline
\end{tabular}

Table 6. Systolic and diastolic blood pressure values according to genotype distributions

\begin{tabular}{|c|c|c|c|c|c|c|c|}
\hline \multirow[b]{2}{*}{ All subjects } & \multicolumn{3}{|c|}{ Co-Dominant Model } & \multicolumn{2}{|c|}{ Dominant Model } & \multicolumn{2}{|c|}{ Recessive Model } \\
\hline & QQ n=101 & QR n=106 & $R R n=23$ & QQ n=101 & QR/RR n=129 & QQ/QR n=207 & $R R \mathbf{n}=23$ \\
\hline $\operatorname{SBP}(n=230)$ & $130(110-140)$ & $120(110-130)$ & $120(110-130)$ & $130(110-140)$ & $120(110-130)$ & $125(110-140)$ & $120(110-130)^{*}$ \\
\hline $\operatorname{DBP}(n=230)$ & $70(70-80)$ & $80(70-80)$ & $70(70-80)$ & $70(70-80)$ & $70(70-80)$ & $70(70-80)$ & $70(70-80)$ \\
\hline $\begin{array}{l}*: p<0.05 \text {; Values } \\
\text { SBP: systolic bloo }\end{array}$ & $\begin{array}{l}\text { e expressed as Med } \\
\text { ressure; DBP: diastol }\end{array}$ & $\begin{array}{l}\text { an (quartile 1-3) } \\
\text { c blood pressure }\end{array}$ & & & & & \\
\hline
\end{tabular}


subgrouping according to blood pressure (hypertensive and normotensive). We found no individuals with RR genotype in the hypertensive group. Systolic blood pressure values were also lower in all the RR subjects, a difference that was only statistically significant under the recessive model, while in other models, the difference was only marginal. Odds ratios showed increased risk of hypertension for the $\mathrm{Q}$ allele compared to $\mathrm{R}$ alelle: $\mathrm{R}$ vs. $\mathrm{Q}$ $(\mathrm{OR}=2.29$ ([\%95 Cl 1.36-3.83], $\mathrm{p}=0.002)$ ). Similarly, this ratio was high in the dominant model (QR+RR vs. QQ: (OR=2.26 ([\%95 Cl 1.21-4.19], $p=0.012$ ). Olivera et al. (42) reported that Gln223Arg polymorphism was associated independently with SBP. Ping Gu et al. (43) reported similar results, showing that the risk of hypertension is higher in $\mathrm{Q}$ allele carriers compared to $\mathrm{R}$ allele carriers. This outcome confirms the potential protective role of the RR genotype against hypertension (Table 6).

The lack of an obese control group in our study has limited us to show the effect of Q223R polymorphism on OSAS. Inclusion of only male population to the study group and relatively small size of the study group which led to under representation of the population have been the other limitations of the study.

According to our results, the LEPR Q223R polymorphism does not appear to be associated with OSAS in men. Our results show that the polymorphism is associated with lower BMI. Lower $\mathrm{AHI}$ and higher NOS levels can be attributed to this decrease in BMI. Subjects carrying a RR genotype were found to have lower blood pressure, supporting the idea that the RR genotype may provide protection against hypertension. OSAS is a multifactorial pathology, and therefore, a single gene mutation cannot form the sole basis for explaining the pathophysiology of the disease. Further studies in larger sample populations encompassing other polymorphisms (Ser343Ser, Ser492Thr, and Lys656Asn) in the LEPR are necessary to further clarify the relationship between LEPR polymorphisms and OSAS.

\section{Acknowledgements}

This study is derived from Master's Program thesis of the first author, and was supported by the Scientific Research Foundation of the Selcuk University, Konya, Turkey (Project No: 09-202036).

\section{REFERENCES}

1. Guilleminault C, Abad VC. Obstructive sleep apnea syndromes. Med Clin North Am 2004; 88(3): 611-30. [CrossRef]

2. Young T, Peppard PE, Gottlieb DJ. Epidemiology of obstructive sleep apnea: a population health perspective. Am J Respir Crit Care Med 2002; 165(9): 1217-39. [CrossRef]

3. Drager LF, Togeiro SM, Polotsky VY, Lorenzi-Filho G. Obstructive sleep apnea: a cardiometabolic risk in obesity and the metabolic syndrome. J Am Coll Cardiol 2013; 62(7): 569-76. [CrossRef]

4. Sánchez-de-la-Torre M, Campos-Rodriguez F, Barbé F. Obstructive sleep apnoea and cardiovascular disease. Lancet Respir Med 2013; 1(1): 61-72. [CrossRef]

5. Frey WC, Pilcher J. Obstructive sleep-related breathing disorders in patients evaluated for bariatric surgery. Obes Surg 2003; 13(5): 676-83. [CrossRef]

6. Vgontzas AN, Bixler EO, Chrousos GP. Sleep apnea is a manifestation of the metabolic syndrome. Sleep Med Rev 2005; 9: 211-24. [CrossRef]
7. Phillips BG, Kato M, Narkiewicz K, Choe I, Somers VK. Increases in leptin levels, sympathetic drive, and weight gain in obstructive sleep apnea. Am J Physiol Heart Circ Physiol 2000; 279: H234-7. [CrossRef]

8. Caro JF, Kolaczynski JW, Nyce MR, Ohannesian JP, Opentanova I, Goldman WH, et al. Decreased cerebrospinal-fluid/serum leptin ratio in obesity: a possible mechanism for leptin resistance. Lancet 1996; 348(9021): 159-61. [CrossRef]

9. Wiesner G, Vaz M, Collier G, Seals D, Kaye D, Jennings G, et al. Leptin is released from the human brain: influence of adiposity and gender. J Clin Endocrinol Metab 1999; 84(7): 2270-4. [CrossRef]

10. Redline S, Tishler PV. The genetics of sleep apnea. Sleep Med Rev 2000; 4(6): 583-602. [CrossRef]

11. Liu YJ, Rocha-Sanchez SM, Liu PY, Long JR, Lu Y, Elze L, et al. Tests of linkage and/or association of the LEPR gene polymorphisms with obesity phenotypes in Caucasian nuclear families. Physiol Genomics 2004; 17(2): 101-6. [CrossRef]

12. Tartaglia LA. The leptin receptor. J Biol Chem 1997; 272(10): 6093-6. [CrossRef]

13. Mantzoros CS. The role of leptin in human obesity and disease: a review of current evidence. Ann Intern Med 1999; 130(8): 671-80. [CrossRef]

14. Ogawa T, Hirose H, Yamamoto $Y$, Nishikai K, Miyashita K, Nakamura $\mathrm{H}$, et al. Relationships between serum soluble leptin receptor level and serum leptin and adiponectin levels, insulin resistance index, lipid profile, and leptin receptor gene polymorphisms in the Japanese population. Metabolism 2004; 53(7): 879-85. [CrossRef]

15. Ragin CC, Dallal C, Okobia M, Modugno F, Chen J, Garte S, et al. Leptin levels and leptin receptor polymorphism frequency in healthy populations. Infect Agent Cancer 2009; 4 Suppl 1: S13. [CrossRef]

16. Chiu KC, Chu A, Chuang LM, Saad MF. Association of leptin receptor polymorphism with insulin resistance. Eur J Endocrinol 2004; 150(5): 725-9. [CrossRef]

17. Shimizu H, Oh-I S, Okada S, Mori M. Leptin resistance and obesity. Endocr J 2007; 54(1): 17-26. [CrossRef]

18. Quinton ND, Lee AJ, Ross RJ, Eastell R, Blakemore Al. A single nucleotide polymorphism (SNP) in the leptin receptor is associated with BMI, fat mass and leptin levels in postmenopausal Caucasian women. Hum Genet 2001; 108(3): 233-6. [CrossRef]

19. Yiannakouris N, Yannakoulia M, Melistas L, Chan JL, Klimis-Zacas D, Mantzoros CS. The Q223R polymorphism of the leptin receptor gene is significantly associated with obesity and predicts a small percentage of body weight and body composition variability. J Clin Endocrinol Metab 2001; 86(9): 4434-9. [CrossRef]

20. Hastuti P, Zukhrufia I, Padwaswari MH, Nuraini A, Sadewa AH. Polymorphism in leptin receptor gene was associated with obesity in Yogyakarta, Indonesia. Egypt J Med Hum Genet 2016; 17(3): 271-6. [CrossRef]

21. Lv D, Tan L, Wu Y, Cao C, Deng Z. Leptin and leptin receptor gene polymorphisms in obstructive sleep apnea: a HuGE review and meta-analysis. Sleep Breath 2015; 19(3): 1073-8. [CrossRef]

22. Schiza SE, Mermigkis C, Bouloukaki I. Leptin and leptin receptor gene polymorphisms and obstructive sleep apnea syndrome: is there an association? Sleep Breath 2015; 19(3): 1079-80. [CrossRef]

23. Izci B, Ardic S, Firat H, Sahin A, Altinors M, Karacan I. Reliability and validity studies of the Turkish version of the Epworth Sleepiness Scale. Sleep Breath 2008; 12(2): 161-8. [CrossRef]

24. Hommel G. A stagewise rejective multiple test procedure based on a modified Bonferroni test. Biometrika 1988; 75(2): 383-6. [CrossRef]

25. World Health Organization. International association for the study of obesity, international obesity task force. The Asia-Pacific perspective: redefining obesity and its treatment 2000: 15-21. 
26. Iber C, Ancoli-Israel S, Chesson A, Quan S. The AASM Manual for the Scoring of Sleep and Associated Events: Rules, Terminology and Technical Specifications. Westchester, Illinois: American Academy of Sleep Medicine, 2007.

27. Anonymous. TURKHAYGEN-I (106G005) In Vitro Conservation and Preliminary Molecular Identification of Some Turkish Domestic Animal Genetic Resources-I. Koban E (Ed.). Tür ve Irkların DNA Iş̧aretleri ile Moleküler Tanımlanması Çalışma Paketi I. Çalıştay. ODTÜ, Ankara. 2007. [Online] Available at: http://www.turkhaygen.gov. tr/doc/egitim_ODTU.pdf. Accessed (12.12.2017).

28. Guizar-Mendoza JM, Amador-Licona N, Flores-Martinez SE, Lopez-Cardona MG, Ahuatzin-Tremary R, Sanchez-Corona J. Association analysis of the Gln223Arg polymorphism in the human leptin receptor gene, and traits related to obesity in Mexican adolescents. J Hum Hypertens 2005; 19(5): 341-6. [CrossRef]

29. R-DevelopmentCoreTeam. R: A language and environment for statistical computing. R Foundation for Statistical Computing. Vienna, Austria. 2010 http://www.R-project.org.

30. Hanaoka M, Yu X, Urushihata K, Ota M, Fujimoto K, Kubo K. Leptin and leptin receptor gene polymorphisms in obstructive sleep apnea syndrome. Chest 2008; 133(1): 79-85. [CrossRef]

31. Huang R, Huang XZ, Li M, Xiao Y, Zhang J. An investigation of the relationship between Lepr gene Gln223Arg polymorphism and obstructive sleep apnea hypopnea syndrome. Zhonghua Jie He He Hu Xi Za Zhi 2003; 26(9): 517-21.

32. Li Z, Wu W, Gu L, Zhao T, Qin G. Lack of association variants of leptin and leptin receptor gene and OSAHS in Chinese Han population. Sleep Biol Rhythms 2016; 14(1): 37-46. [CrossRef]

33. Popko K, Gorska E, Wasik M, Stoklosa A, Plywaczewski R, Winiarska $M$, et al. Frequency of distribution of leptin receptor gene polymorphism in obstructive sleep apnea patients. J Physiol Pharmacol 2007; 58 Suppl 5: 551-61.

34. Stefan N, Vozarova B, Del Parigi A, Ossowski V, Thompson DB, Hanson $\mathrm{RL}$, et al. The Gln223Arg polymorphism of the leptin receptor in Pima Indians: influence on energy expenditure, physical activi- ty and lipid metabolism. Int J Obes Relat Metab Disord 2002; 26: 1629-32. [CrossRef]

35. Gotoda T, Manning BS, Goldstone AP, Imrie H, Evans AL, Strosberg $A D$, et al. Leptin receptor gene variation and obesity: lack of association in a white British male population. Hum Mol Genet 1997; 6(6): 869-76. [CrossRef]

36. Mergen $H$, Karaaslan C, Mergen M, Deniz Ozsoy E, Ozata M. LEPR, ADBR3, IRS-1 and 5-HTT genes polymorphisms do not associate with obesity. Endocr J 2007; 54(1): 89-94. [CrossRef]

37. Ben Ali S, Kallel A, Sediri Y, Ftouhi B, Feki M, Slimene H, et al. LEPR p.Q223R Polymorphism influences plasma leptin levels and body mass index in Tunisian obese patients. Arch Med Res 2009; 40(3): 186-90. [CrossRef]

38. Chagnon YC, Chung WK, Perusse L, Chagnon M, Leibel RL, Bouchard C. Linkages and associations between the leptin receptor (LEPR) gene and human body composition in the Quebec Family Study. Int J Obes Relat Metab Disord 1999; 23(3): 278-86. [CrossRef]

39. Wauters M, Mertens I, Chagnon M, Rankinen T, Considine RV, Chagnon YC, et al. Polymorphisms in the leptin receptor gene, body composition and fat distribution in overweight and obese women. Int J Obes Relat Metab Disord 2001; 25(5): 714-20. [CrossRef]

40. Heo M, Leibel RL, Boyer BB, Chung WK, Koulu M, Karvonen MK, et al. Pooling analysis of genetic data: the association of leptin receptor (LEPR) polymorphisms with variables related to human adiposity. Genetics 2001; 159(3): 1163-78.

41. Rosmond R, Chagnon YC, Holm G, Chagnon M, Perusse L, Lindell K, et al. Hypertension in obesity and the leptin receptor gene locus. J Clin Endocrinol Metab 2000; 85(9): 3126-31. [CrossRef]

42. Oliveira Rd, Cerda A, Genvigir FDV, Sampaio MF, Armaganijan D, Bernik MMS et al. Leptin receptor gene polymorphisms are associated with adiposity and metabolic alterations in Brazilian individuals. Arq Bras Endocrinol Metabol 2013; 57: 677-84. [CrossRef]

43. Gu P, Jiang W, Chen M, Lu B, Shao J, Du H et al. Association of leptin receptor gene polymorphisms and essential hypertension in a Chinese population. J Endocrinol Invest 2012; 35: 859-65. 